\title{
Measurements of the relation between aerosol properties and microphysics and chemistry of low level liquid water clouds in Northern Finland
}

\author{
H. Lihavainen ${ }^{1}$, V.-M. Kerminen ${ }^{1}$, M. Komppula ${ }^{2}$, A.-P. Hyvärinen ${ }^{1}$, J. Laakia ${ }^{1}$, S. Saarikoski ${ }^{1}$, U. Makkonen ${ }^{1}$, \\ N. Kivekäs ${ }^{1}$, R. Hillamo ${ }^{1}$, M. Kulmala ${ }^{3}$, and Y. Viisanen ${ }^{1}$ \\ ${ }^{1}$ Finnish Meteorological Institute, P.O. Box 503, 00101 Helsinki, Finland \\ ${ }^{2}$ Finnish Meteorological Institute, P.O. Box 1627, 70211 Kuopio, Finland \\ ${ }^{3}$ University of Helsinki, Dept. of Physics, P.O. Box 64, 00014 Univ. of Helsinki, Finland
}

Received: 21 May 2008 - Published in Atmos. Chem. Phys. Discuss.: 23 July 2008

Revised: 30 September 2008 - Accepted: 30 September 2008 - Published: 1 December 2008

\begin{abstract}
Physical and chemical properties of boundary layer clouds, together with relevant aerosol properties, were investigated during the first Pallas Cloud Experiment (First Pace) conducted in northern Finland between 20 October and 9 November 2004. Two stations located $6 \mathrm{~km}$ apart from each other at different altitudes were employed in measurements. The low-altitude station was always below the cloud layer, whereas the high-altitude station was inside clouds about $75 \%$ of the time during the campaign. Direct measurements of cloud droplet populations showed that our earlier approach of determining cloud droplet residual particle size distributions and corresponding activated fractions using continuous aerosol number size distribution measurements at the two stations is valid, as long as the cloud events are carefully screened to exclude precipitating clouds and to make sure the same air mass has been measured at both stations. We observed that a non-negligible fraction of cloud droplets originated from Aitken mode particles even at moderatelypolluted air masses. We found clear evidence on first indirect aerosol effect on clouds but demonstrated also that no simple relation between the cloud droplet number concentration and aerosol particle number concentration exists for this type of clouds. The chemical composition of aerosol particles was dominated by particulate organic matter (POM) and sulphate in continental air masses and POM, sodium and chlorine in marine air masses. The inorganic composition of cloud water behaved similarly to that of the aerosol phase and was not influenced by inorganic trace gases.
\end{abstract}

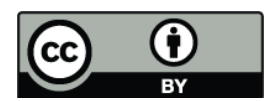

Correspondence to: $\mathrm{H}$. Lihavainen (heikki.lihavainen@fmi.fi)

\section{Introduction}

Clouds constitute perhaps the largest source of uncertainty in predicting the behavior of the Earth's climate system (IPCC, 2007; Baker and Peter, 2008). Many of the climatically important cloud properties, including the reflectivity, lifetime and precipitation patterns of clouds, depend strongly on atmospheric aerosol particles. The essential cloud microphysical parameters in studying aerosol-cloud-climate interactions are the total number concentration and effective radius of cloud droplets, cloud liquid water content and the relative dispersion of a cloud droplet population (e.g. Lu and Seinfeld, 2006; Ekman et al., 2007; Liu et al., 2007; Bulgin et al., 2008).

Global climate model simulations and satellite measurements are ultimately the only means to determine the connection between atmospheric aerosols, clouds and Earth's climate system. Unfortunately, both these approaches are subject to large uncertainties at the moment. Global model simulations suffer from our poor understanding of the underlying processes, as well as from the lack of computational resources (Lohman and Feichter, 2005; Penner et al., 2006). In case of satellite measurements multiple sources of uncertainty exist (e.g. Koren et al., 2007; Mauger and Norris, 2007; Myhre et al., 2007), in addition to which satellites are unable to measure cloud and aerosol properties at exactly the same time and space. Reported climate forcing estimates associated with aerosol-cloud interactions are usually substantially lower for satellite-based estimates as compared with climate model simulations (McComiskey and Feingold, 2008; Quaas et al., 2008).

Published by Copernicus Publications on behalf of the European Geosciences Union. 
Aircraft measurements and observations at elevated stations provide a complementary way to investigate aerosolcloud interactions, especially what it comes to the dependence of various cloud properties on the size distribution and chemical composition of the underlying aerosol particle population. Here, we summarize our main findings from the First Pallas Cloud Experiment (First PaCE) conducted at a remote continental site in Northern Finland from 18 October to 9 November 2004. During the First PaCE, a versatile set of chemical and physical measurements for both aerosols and clouds were made simultaneously. Our main goals in this paper are i) to demonstrate the performance of the method developed by Komppula et al. (2005) for determining the cloud droplet activating properties of aerosols from continuous size distribution measurements, ii) to provide additional data on how particles of different size are activated into cloud droplets in different air mass types, and iii) to get further insight into the connections between cloud microphysics, aerosol number size distribution and associated chemistry.

\section{Measurements}

\subsection{Site description}

Measurements were done in the Pallas GAW (Global Atmosphere Watch) station hosted by the Finnish Meteorological Institute. The two aerosol measurement sites in Pallas, Sammaltunturi $\left(67^{\circ} 58^{\prime} \mathrm{N}, 24^{\circ} 07^{\prime} \mathrm{E}, 565 \mathrm{~m}\right.$ a.s.l. $)$ and Matorova $\left(68^{\circ} 00^{\prime} \mathrm{N}, 24^{\circ} 14^{\prime} \mathrm{E}, 340 \mathrm{~m}\right.$ a.s.l.), are located $6 \mathrm{~km}$ away from each other. The higher-altitude station Sammaltunturi is inside a cloud during, on average, $5 \%$ of all days, whereas the Matorova station is almost always below the cloud layer. For a more detailed description of the site see Hatakka et al. (2003).

\subsection{Field instrumentation}

\subsubsection{Sammaltunturi, in-cloud station}

At the Sammaltunturi station, all the air samples into the instruments are taken from a single, main sample line. A more detailed description of the sampling line can be found in Komppula et al. (2005) and only brief description is given here. The inlet of the main sampling is about $7 \mathrm{~m}$ above the ground and about $3 \mathrm{~m}$ above the roof of the station. The inner diameter of the stainless steel inlet nozzle and main sampling line is $56 \mathrm{~mm}$. The air flow rate in the main sampling line is about $90 \mathrm{~m}^{3} / \mathrm{h}$. The sampling nozzle is H-shaped, leading to two downward- and two upward-orientated inlets with a flow rate of about $22.5 \mathrm{~m}^{3} / \mathrm{h}$ through each of them. The outer surface of the nozzle is heated slightly above $0^{\circ} \mathrm{C}$ in order to avoid the build up of ice and snow. There are three $90^{\circ}$ turns and about $4 \mathrm{~m}$ of horizontal sampling line before the air arrives to the region, from which it is drawn into the aerosol instruments. The diameter of 50\% particle transmission efficiency with this arrangement was calculated to be about $7 \mu \mathrm{m}$ for ambient air conditions and with an average wind speed $(6.4 \mathrm{~m} / \mathrm{s})$ in data analysed here. This diameter varied by few $\mu \mathrm{m}$ with wind speed extremes. Calculations were made according to the equations presented in Baron and Willeke (2001). In the analysis described below, it was assumed that all particles larger than $7 \mu \mathrm{m}$ in diameter were cloud droplets. Based on the FSSP data analysis the uncertainty caused by the cut off size is rather small, as the median precentage of the cloud droplets below $7 \mu \mathrm{m}$ was about $2.5 \%$ (average $8.3 \%$ ).

Cloud droplet number size distributions $(3-32 \mu \mathrm{m}$ or 3$47 \mu \mathrm{m})$ were measured with a model SPP-100 Forward Scattering Spectrometer Probe (FSSP, Particle Measuring Systems Inc, USA) with upgraded electronics (Droplet Measurement Technologies, Boulder, Colorado, USA). A more detailed description of the instrument can be found for example in Brenguier (1989). The FSSP was placed onto a rotating platform, so that the inlet was always against the wind. Supercooled cloud droplets blocked the flow laminator of the FSSP, so it needed periodical cleaning and could not be run continuously. The cleaning of the laminator after about every $15 \mathrm{~min}$ can be seen from the raw data. Measured number concentrations started to decrease within a few minutes after the cleaning, which is a sign that the laminator started to get blocked and flow through the system decreased. The blocking was also visually observed. For the final analyses presented later, only the data measured right after the cleaning was taken into account. The FSSP was operational from 25 October to the end of the campaign. Since droplet concentrations during the operation of FSSP were low $\left(<300 \mathrm{~cm}^{-3}\right)$, the FSSP data was not corrected for coincidence or dead-time losses (Baumgardner et al., 1985). The FSSP was calibrated after the campaign.

Cloud water was collected for chemical analysis using a fog water collector (Korhonen and Viisanen, 1995). The fog collector utilizes a single stage Teflon impactor plate with a rectangular inlet throat. The throat dimensions of the collector are $12 \times 1.4 \mathrm{~cm}$ and the jet-to-plate distance is $2.1 \mathrm{~cm}$. The flow rate used in the collector was about $130 \mathrm{~m}^{3} / \mathrm{h}$. The calculated minimum collected diameter of the fog water collector was $7 \mu \mathrm{m}$. During this campaign, temperatures were often below the freezing point. This caused that in this instrument, supercooled cloud droplets froze onto the collection plate. This changed the cut off diameter to lower particle sizes. After enough "ice" was collected onto the plate, the fog water collector was sealed and taken inside the station to melt. The cloud water samples were collected with an average collection time of about $1 \mathrm{~h}$ and $10 \mathrm{~min}$. 


\subsubsection{Matorova, below-cloud station}

At the Matorova station, the air sample was drawn straight to the DMPS through a stainless steel tube having a 1-inch inner diameter. The sample was taken about $2 \mathrm{~m}$ above the roof and $4 \mathrm{~m}$ above the ground. There was a $\mathrm{PM}_{10}$ nozzle at the top of the sample line.

Aerosol samples for chemical and gravimetic analysis were collected at the Matorova station. A filter aerosol sampling system similar to that in Saarikoski et al. (2005) was used in this study. Briefly, ambient air samples were collected using a modified virtual impactor (VI) similar to that in Loo and Cork (1988), as well as using a small deposit area impactor (SDI, Maenhaut et al., 1996). The VI divides aerosols by their aerodynamic diameter into two size fractions, fine $(<1.3 \mu \mathrm{m})$ and coarse $(1.3-10 \mu \mathrm{m})$. Air samples for the VI were collected onto filters for weighting and ionic analysis. The filter material was PTFE (Millipore Fluoropore, $3.0 \mu \mathrm{m} 47 \mathrm{~mm}$ ). The 12 stages of the SDI have aerodynamic cut-off diameters of $0.045,0.086,0.153,0.231,0.343$, $0.591,0.796,1.06,1.66,2.68,4.08$ and $8.5 \mu \mathrm{m}$. Substrates for the SDI stages were manufactured from an aluminum foil that was covered with a polycarbonate film (poreless film from Nuclepore Inc., thickness $10 \mu \mathrm{m}$ ). A thin layer of Apiezon L vacuum grease was used to minimize the particle bounce from the impactor substrate. A similar system (VI and SDI) was used to collect samples for a subsequent analysis of organic (OC) and elemental carbon (EC) by using quartz fiber filters as a sampling matrix (Whatman QMA, diameter $47 \mathrm{~mm}$ ).

Denuders were used to remove interfering organic gases from the sample in the carbon aerosol sampling. Unfortunately, this system may cause diffusion and particle impaction losses. Since this part of the study was focused on aerosol mass and since diffusion losses concern mainly ultrafine particles having a low mass concentration, the diffusion losses were neglected in our analysis. Particles with an aerodynamic diameter larger than $5 \mu \mathrm{m}$ have wall looses in sharp angles (Haglund and McFarland, 2004). This effect increases with an increasing particle size (McFarland et al., 1997). All the instruments were connected to the same sample line. This system included two $90^{\circ}$ bends. During the campaign snow and ice covered the terrain and therefore coarse particle concentrations were relatively small. Sampling periods alternated from 2 to 4 days. Relatively long sampling periods were necessary due to the low concentrations of particles.

\subsubsection{Instruments at both stations}

Similar DMPS (Differential Mobility Particle Sizer) systems are used at both sites for nanometre particle sizing for the dry particle diameter range of 7-500 $\mathrm{nm}$. The DMPSs are built up with a 28-cm-long Hauke-type differential mobility analyser (DMA) (Winklmayr et al., 1991) with a closed loop sheath flow arrangement (Jokinen and Mäkelä, 1997) and a condensation particle counter (CPC 3010, TSI Inc., USA). Before sizing, the aerosol is neutralised with a $370 \mathrm{MBq}$ Nickel-63 beta source. The used sheath air flow rate is about $11.01 \mathrm{~min}^{-1}$ and sample aerosol flow rate is $1.01 \mathrm{~min}^{-1}$. The measured particle size range is divided into 30 discrete bins. The DMPS systems are equipped with sensors for the sheath air temperature, pressure and relative humidity. The sheath air is kept at a relatively low and constant humidity (less than $20 \%$ ) with a silicagel dryer. One particle size spectrum takes around five and a half minutes to be measured ( 30 bins times $10 \mathrm{~s}$ plus decreasing the voltage from highest value to zero). The daily temperature and pressure means are used to improve the accuracy of result calculations. Before the measurements were started, the instruments were calibrated with silver particles at the University of Helsinki with a method similar to that presented by Aalto et al. (2001).

With the DMPS setup described above, we were able to measure simultaneously the cloud interstitial particle size spectrum from the in-cloud station and residual particle size spectrum from the nearby below-cloud station. The number concentration and fraction of activated particles for all size bins could be estimated by comparing the in-cloud and outof-cloud size spectra. Total particle number concentrations (particles with diameter, $d$, larger than $10 \mathrm{~nm}$ ) were also measured at both stations using condensation particle counters (CPC 3010, TSI inc., USA).

Weather parameters were measured at both stations using an automatic weather station. The measured parameters were the temperature, pressure, relative humidity, and wind speed and direction. At the Sammaltunturi station, there were also sensors for present weather and total global radiation.

\subsection{Chemical analysis of the samples}

Aerosol samples were analysed for ions by using two ions chromatographs (ICs; Dionex 500). OC and EC were determined with the thermal-optical transmission method using a carbon analyser developed by Sunset Laboratory Inc., Oregon. The analytical methods for the aerosol samples are described in detail by Saarikoski et al. (2005). The detection limits for OC, EC, methanesulfonic acid, chloride, nitrate, sulfate, oxalate, sodium, ammonium, potassium, magnesium and calsium analyzed from the aerosol samples were $48,36,1.27,0.27,0.14,2.8,0.17,0.29,0.25,0.13,0.44$ and $2.1 \mathrm{ng} / \mathrm{m}^{3}$, respectively. Similar to the aerosol samples, the cloud water was analysed with the ICs for the major inorganic ions.

\subsection{Data processing}

Hourly averages of particle number size distributions were calculated from both stations. The number concentration of activated particles, $A_{\text {tot }}\left(\mathrm{cm}^{-3}\right)$, was calculated by subtracting the interstitial particles number size distribution 
measured at the in-cloud station from the total particle number size distribution measured at the below-cloud station. The subtraction was done separately for each size bin. If the subtraction resulted in a negative value, the value was set to zero to avoid unphysical situation. The effect of this procedure to total number of activated cloud droplets was tested and it fell well within the uncertainities in aerosol particle concentrations resulting from the accuracies of the DMPS systems themselves. The sum of particle number concentration in the subtracted bins was then the total number concentration of activated particles. From the same data, the activated (or scavenging) fraction of particles in each size bin was calculated by dividing the number of activated particles in that bin by the total number of particles in the same bin. The diameter of $50 \%$ activation efficiency $\left(D_{50}\right)$ was defined as the size at which the activated fraction rose over $50 \%$. The number concentration of activated particles and activated fraction were also estimated for the different modes, including the nucleation mode (10-25 nm), Aitken mode (25$95 \mathrm{~nm})$ and accumulation mode $(95-500 \mathrm{~nm})$. The nucleation mode was not included in calculating the total cloud droplet number concentration, since particles in this mode are normally too small to be activated into cloud droplets, and since this mode can be affected significantly by scavenging and growth processes.

The measured air masses in the two stations were not necessarily always the same because of the distance between the stations and because of the orographic features of the surroundings. Careful analyses of the size distributions and total number concentrations were done to assure that the measured air mass in the analyses presented here was approximately the same at both stations. First, the data with observed rain was left out from the analysis. Second, when comparing the DMPS-evaluated properties of activation to directly-measured cloud droplet number concentrations with the FSSP, the DMPS data were excluded if the hourlyaveraged size distributions in the range $20-40 \mathrm{~nm}$ were different by more than $30 \%$ between the measurement sites. The outcome of this latter procedure did not change significantly when using a lower percentage limit. In the case studies the size distributions and total number concentrations should be quite stable during the event. While the above screening procedures cannot guarantee that the air masses measured at the two stations were the same, we believe the resulting uncertainties in the analyses presented later are minor.

The cloud droplet effective radius, $R_{\text {eff }}$, and cloud liquid water content (LWC) were calculated from the FSSP data by using the following equations:

$$
R_{\mathrm{eff}}=\frac{1}{2} \sum_{i=1}^{30} N_{i} D_{i}^{3} / \sum_{i=1}^{30} N_{i} D_{i}^{2}
$$

$\mathrm{LWC}=\frac{\pi}{6} \rho_{w} \sum_{i=1}^{30} N_{i} D_{i}^{3}$

where $D_{i}$ and $N_{i}$ are the cloud droplet size and number of cloud droplets in the bin number $i$, respectively, and $\rho_{w}$ is the density of liquid water. The FSSP was calibrated after the campaign and the results were corrected accordingly.

The indirect effect (IE), or aerosol-cloud interaction (ACI), was calculated using the following relation (McComiskey and Feingold, 2008):

$\mathrm{ACI}=\frac{1}{3} \frac{d \ln N_{d}}{d \ln \alpha}$

where $N_{d}$ is number concentration of cloud droplets and $\alpha$ in some proxy for the aerosol burden, such as the aerosol optical depth, number concentration of aerosol particles or aerosol light scattering coefficient. We used the total particle number concentration for this proxy, calculating it as the sum of measured cloud droplet number concentration and interstitial particle number concentration at the in-cloud station.

\section{Results}

\subsection{Overview of the results}

The measurement campaign took place between 20 October 2004 and 9 November 2004 (day of the year: 294-314). The meteorological conditions at the measurement site during the campaign were affected by passages of several depressions from the South-West with associated overcast and variable winds for most of the time. High pressures and fair skies over at the measurement site were present in only few occasions. During the campaign, the Sammaltunturi station was inside a cloud for about $75 \%$ of the time. The average temperature was $-3^{\circ} \mathrm{C}$ and varied between $-8^{\circ} \mathrm{C}$ and $+5^{\circ} \mathrm{C}$. Figure 1 shows the total particle number concentration $\left(N_{\text {tot }}\right.$, particle diameter $>10 \mathrm{~nm})$ at the two stations and the number concentration of cloud droplets $\left(A_{\text {tot }}\right)$, as measured directly with the FSSP and derived from the DMPS systems. The overall average particle number concentration at the Matorova station was $260 \mathrm{~cm}^{-3}$, with hourly averages varying between 30 and $1200 \mathrm{~cm}^{-3}$ depending on the history of the measured air mass. Low particle number concentrations were related to air masses coming almost directly from the Arctic Ocean, whereas high particle number concentrations were associated with continental air masses coming from west and south or with air influenced by the Kola Peninsula industrial area in Russia 350-400 km east of our measurement site.

Direct cloud droplet concentration measurements from the FSSP were compared with those evaluated from the DMPS measurements (Fig. 2). The comparison was made for onehour averages. The FSSP was operational from 25 October (day of the year: 299) to the end of the campaign but it could not be run continuously (see Sect. 2.2.1). As it can be seen, the two methods of determining the cloud droplet number 


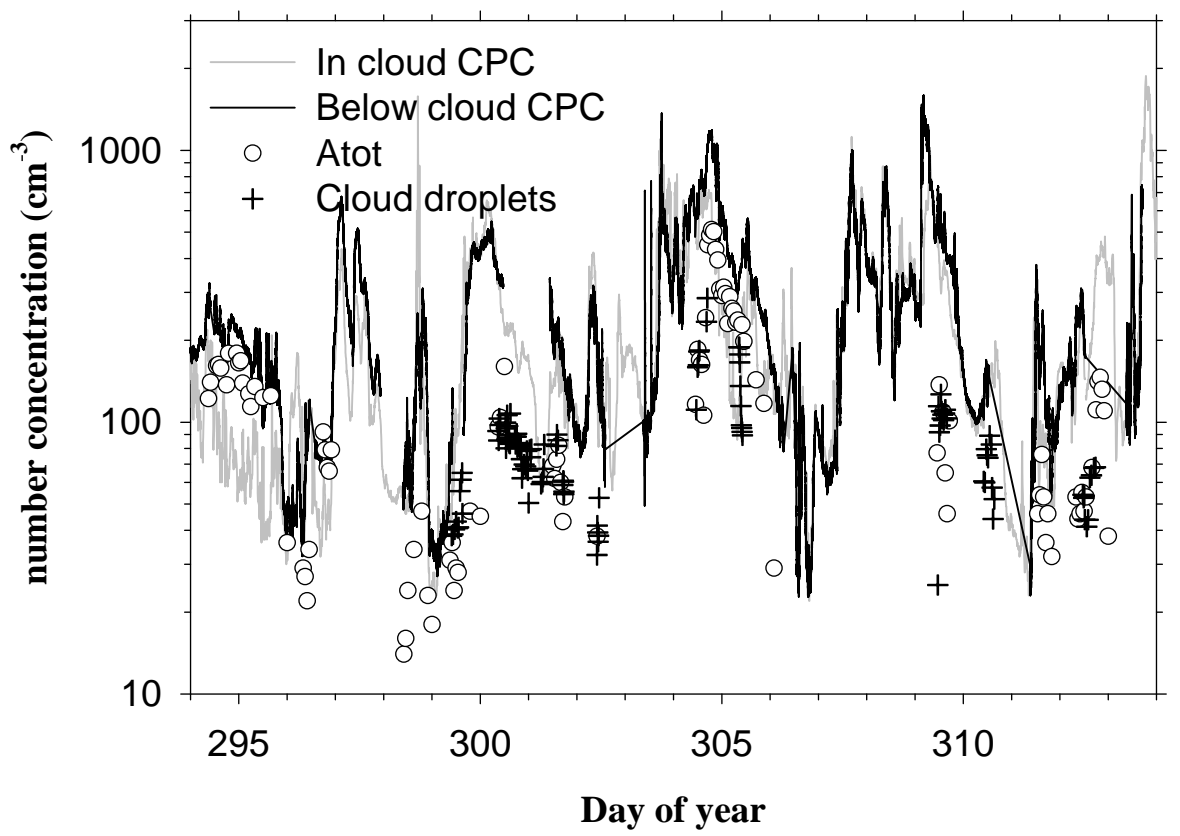

Fig. 1. Variation of aerosol and cloud droplet population during the campaign. $A_{\text {tot }}$ is concentration of activated particles calculated from DMPS size distributions and cloud droplets is directly measured with FSSP. In cloud CPC measured the number concentration of interstitial aerosols and Below cloud CPC the total aerosol number concentration.

concentration agreed very well despite their totally different approach and 6-km distance between the below- and in-cloud stations. This confirms that the DMPS-based measurement approach introduced by Komppula et al. (2005) is valid as long as we are measuring approximately the same air masses at the two stations.

\subsection{Aerosol population and cloud droplets}

Four cloud events with stable conditions were identified from the measured aerosol data. Although the total particle number concentrations varied slightly during all the events, the measured air masses were the same at the two stations, as were also the shapes of the particle number size distributions (Fig. 3). For each event, average aerosol and cloud droplet activation properties are presented in Table 1, while corresponding meteorological conditions are summarized in Table 2. The FLEXTRA trajectory model (e.g. Stohl and Seibert, 1998) was used to investigate the history of air mass for each event up to $120 \mathrm{~h}$ prior to arrival of air at the measurement site.

During the first event continental air masses originating from west Russia, and travelling to the measurement site through southern Finland and northern Sweden, were prevailing. The accumulation mode was very dominant during the event, which might be indicative of scavenging of smaller particles by rain during the transport. Due to the low value of $D_{50}$ and dominating accumulation mode, the overall activated fraction was quite high (70\%). In the ac-

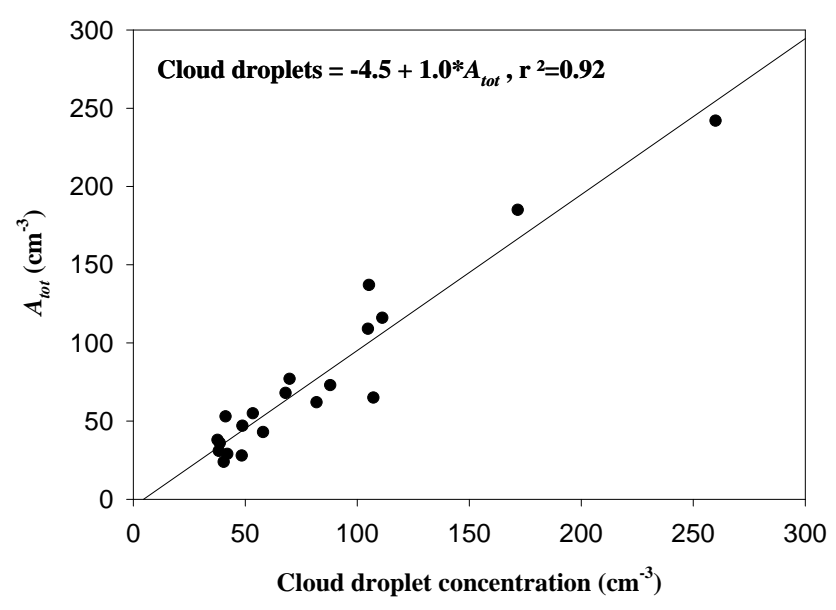

Fig. 2. Comparison of concentration of directly measured cloud droplets and DMPS evaluated concentration of cloud droplets, $A_{\text {tot }}$. The solid line is a linear fitting to the data, the fitting formula is presented in the figure.

cumulation mode this fraction was $89 \%$ and in the Aitken mode it was only $12 \%$. During the second event the measured air masses originated from the Arctic Ocean but travelled through Sweden and Finland before arriving at our site. The particle number size distribution was bimodal having about equal Aitken and accumulation modes. The total particle number concentration was the highest of the four 

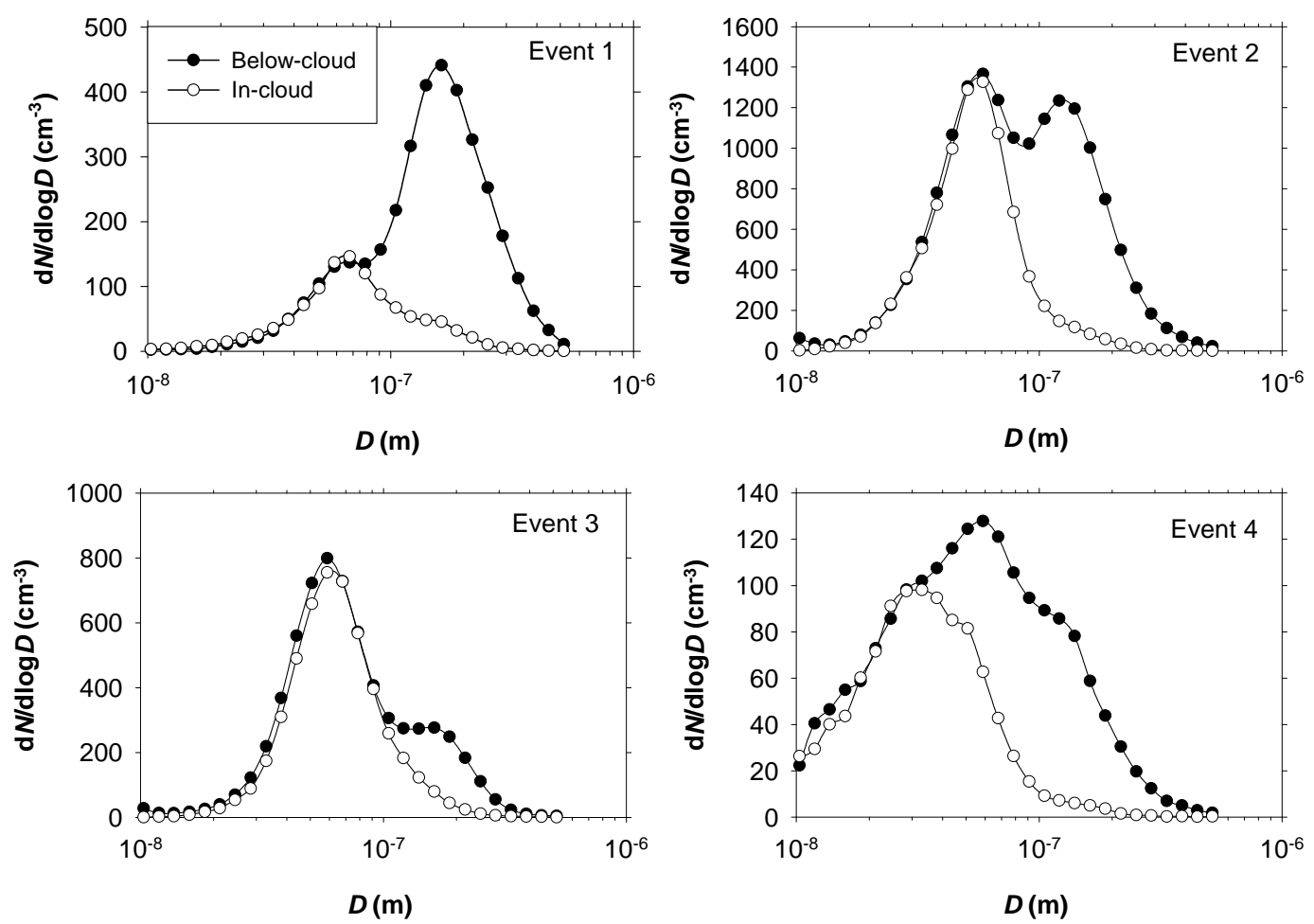

Fig. 3. Size distribution in four selected events during the campaign period. Notice different scaling of vertical axis.

Table 1. Average aerosol and cloud droplet activation properties for the different events. $N_{\text {tot }}$ is total particle number concentration, $D_{50}$ is the dry diameter of aerosols at which the activated fraction exceeds $50 \%, A_{i}$ is the number concentration of activated particles (=cloud droplets) and $A f_{i}$ is the fraction of activated particles. The subscripts tot, acc and Ait refer to the total aerosol, accumulation mode and Aitken mode, respectively.

\begin{tabular}{rrrrrrrrrrrr}
\hline $\begin{array}{r}N_{\text {tot }} \\
\left(\mathrm{cm}^{-3}\right)\end{array}$ & $\begin{array}{r}D_{50} \\
(\mathrm{~nm})\end{array}$ & $\begin{array}{r}A_{\text {tot }} \\
\left(\mathrm{cm}^{-3}\right)\end{array}$ & $\begin{array}{r}A f_{\text {tot }} \\
(\%)\end{array}$ & $\begin{array}{r}N_{\text {acc }} \\
\left(\mathrm{cm}^{-3}\right)\end{array}$ & $\begin{array}{r}A_{\text {acc }} \\
\left(\mathrm{cm}^{-3}\right)\end{array}$ & $\begin{array}{r}A f_{\text {acc }} \\
(\%)\end{array}$ & $\begin{array}{r}N_{\text {Ait }} \\
\left(\mathrm{cm}^{-3}\right)\end{array}$ & $\begin{array}{r}A_{\text {Ait }} \\
\left(\mathrm{cm}^{-3}\right)\end{array}$ & $\begin{array}{r}A f_{\text {Ait }} \\
(\%)\end{array}$ & $\begin{array}{r}\text { Time period } \\
(\text { day of year })\end{array}$ \\
\hline 1 & 229 & 94 & 162 & 70 & 173 & 155 & 89 & 53 & 7 & 12 & $294.79-295.21$ \\
2 & 1001 & 83 & 470 & 48 & 413 & 370 & 90 & 549 & 39 & 18 & $304.71-304.92$ \\
3 & 409 & 137 & 97 & 24 & 112 & 65 & 58 & 283 & 23 & 9 & $309.54-309.83$ \\
4 & 114 & 58 & 55 & 49 & 27 & 25 & 92 & 63 & 27 & 41 & $311.54-311.75$ \\
\hline
\end{tabular}

events. The total activated fraction was $48 \%$. During the third event air masses came from the Northern Atlantic to the measurement site and the particle number size distribution was dominated by the Aitken mode. The activated fraction was the lowest and the value of $D_{50}$ was the highest of the events considered here. This could be explained by the low wind velocity compared with the other events (Table 2). A low wind velocity is indicative of a low updraft velocity in an orographic cloud, resulting in a low supersaturation during the cloud droplet activation (see the analysis below). The fourth event represented very clean air mass coming directly from the Arctic Ocean. As one might expect, the to- tal particle number concentration was very low. The overall activated fraction was $49 \%$ and even for the Aitken mode it was $41 \%$. The value of $D_{50}$ was the lowest $(58 \mathrm{~nm}$ ) of all the four cases.

The relation between the measured below-cloud particle number concentration, either the total number concentration (particles $>10 \mathrm{~nm}$ in dry diameter) or accumulation mode number concentration ( $>95 \mathrm{~nm}$ ), and the number concentration of activated particles (cloud droplets) are presented in Figs. 4 and 5 for each event, together with similar data from other investigations. The aircraft measurements by Twohy et al. (2005) were conducted in northeastern Pacific Ocean, 
Table 2. Average values of meteorological parameters at the Sammaltunturi station during the selected cloud events. $T$ is the temperature, $P$ is the pressure, $W s$ is the horizontal wind speed and $W d$ is the horizontal wind direction.

\begin{tabular}{lllrrr}
\hline $\begin{array}{l}T \\
\left({ }^{\circ} \mathrm{C}\right)\end{array}$ & $\begin{array}{l}P \\
(\mathrm{hPa})\end{array}$ & $\begin{array}{r}W s \\
(\mathrm{~m} / \mathrm{s})\end{array}$ & $\begin{array}{r}W d \\
\left({ }^{\circ} \mathrm{C}\right)\end{array}$ & $\begin{array}{r}\text { Time period } \\
(\text { day of year })\end{array}$ \\
\hline 1 & -3.8 & 943 & 6.8 & 236 & $294.79-295.21$ \\
2 & -3.5 & 943 & 10.3 & 210 & $304.71-304.92$ \\
3 & -1.0 & 935 & 3.8 & 93 & $309.54-309.83$ \\
4 & -0.9 & 944 & 9.3 & 24 & $311.54-311.75$ \\
\hline
\end{tabular}

while those by Martin et al. (1994) were made in four different locations: over eastern Pacific ocean off the coast off the southern coast of California, in the South Atlantic, over the sea areas over the British Isles and in the North Atlantic in the vicinity of Azores. Of mountain top measurements, we have included those by Henning et al. (2002) conducted in a high-alpine site Jungfraujoch, Switzerland, and those by Martinsson et al. (1999) conducted in the northwestern part of England. The measurements by McFarquhar and Heymsfield (2001) were made during the INDOEX experiment over Indian Ocean. We can easily see that no simple relation between the cloud droplet number concentration and total or accumulation mode particle number concentration applicable to all situations can be derived. For example, at accumulation mode number concentration of $400 \mathrm{~cm}^{-3}$, the maximum difference in the number of cloud droplets between the different studies is over $80 \%$. Twohy et al. (2005) noted that the differences between their study and that by McFarquhar and Heymsfield (2001) might be partly related to different vertical velocities at the cloud base. Our study and that by Henning et al. (2002) showed cloud droplet number concentrations that were higher than accumulation mode particle number concentrations, which indicates cloud droplets originating from Aitken mode particles.

Besides the aerosol number concentration, the number concentration of cloud droplets is expected to depend on the updraft velocity of the air forming the cloud, on the shape of the particle number size distribution and on the hygroscopic properties (water solubility) of the aerosol particle population. In order to shed some light on this, we simulated each cloud event using a simple adiabatic cloud parcel model (Anttila and Kerminen, 2002; Korhonen et. al, 2005). As model inputs, we took the measured particle number size distributions and assumed that the water-soluble fraction of all aerosol particles was equal to $50 \%$. This soluble fraction is rough estimate for the whole campaign based on available chemical data (see Kivekäs et al., 2008). The air updraft velocities that gave the best prediction for the observed values of $D_{50}$ and $A_{\text {tot }}$ were about $0.3,0.7,0.1$ and $0.5 \mathrm{~m} / \mathrm{s}$ for the cloud events 1, 2, 3 and 4, respectively. The corresponding maximum supersaturations reached by the clouds were equal

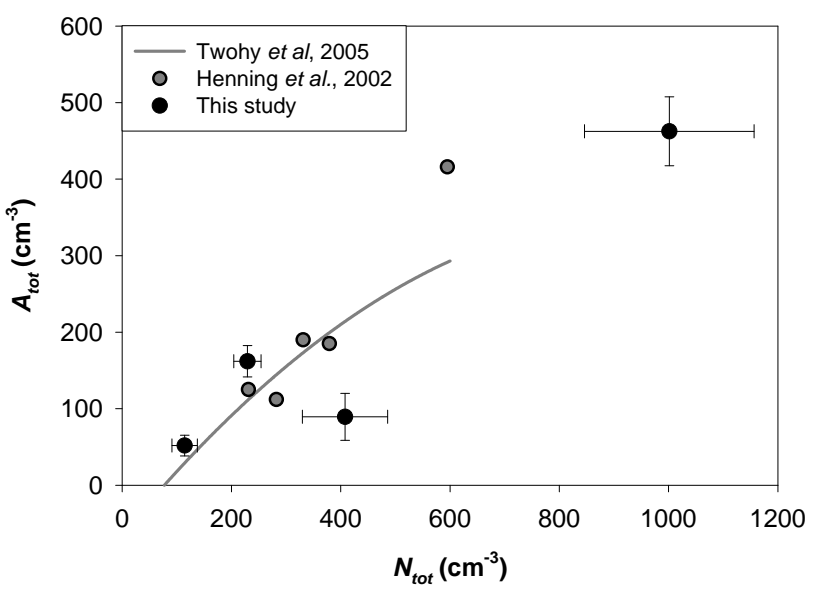

Fig. 4. Relationship of cloud droplet number concentration, $A_{\text {tot }}$, on total aerosol number concentration, $N_{\text {tot }},(d>10 \mathrm{~nm}$ in dry diameter). Four events are from this study, error bars are represents standard deviation during the event. The grey line is data by Twovy et al. (2005) and grey circles are data by Henning et al. (2002).

to $0.2,0.3,0.2$ and $0.5 \%$. These values are comparable to what has usually been observed in stratiform clouds (e.g. Seinfeld and Pandis, 2006). The air updraft velocities obtained for the cloud events are proportional to horizontal wind velocity, so that at higher horizontal wind velocities the updraft velocity was higher. This explains the high value of $D_{50}$ for event 3 as compared with the other events considered here, as well as the apparent discrepancy of this event from the other measurements in Fig. 4. The very high cloud droplet number concentration for event 2 was ascribed to the combination of very high air updraft velocity and relatively large number of accumulation mode particles. Although the updraft velocity was the second lowest in event 1 , the activation fraction was the highest because the particle number size distribution was dominated by the accumulation mode, with $76 \%$ of particles being located in this mode.

Cloud droplet effective radius, $R_{\text {eff }}$, is an essential cloud microphysical parameter that can be related to the Twomey effect (Twomey, 1974; McComiskey and Feingold, 2008), or the first aerosol indirect effect, and to the initiation of warm rain processes (e.g. Rosenfeld and Lensky, 1998). In line with the Twomey effect, the general decrease in $R_{\text {eff }}$ with an increasing aerosol burden has been detected by in situ observations (e.g. Henning et al., 2002), aircraft measurements (e.g. Twohy et al., 2005; Freud et al., 2008), and various remote sensing methods (e.g. Feingold et al., 2003; Bulgin et al., 2008). Since only few FSSP measurement were done in parallel to acceptable aerosol measurements (see Fig. 2), we took a slightly different approach in linking cloud droplet and aerosol particle concentrations. We plotted the relation between $R_{\text {eff }}$ and aerosol burden by adding together the concentrations of cloud droplets and cloud interstitial particles $(>10 \mathrm{~nm})$ at the in-cloud station (Fig. 6). The data were 


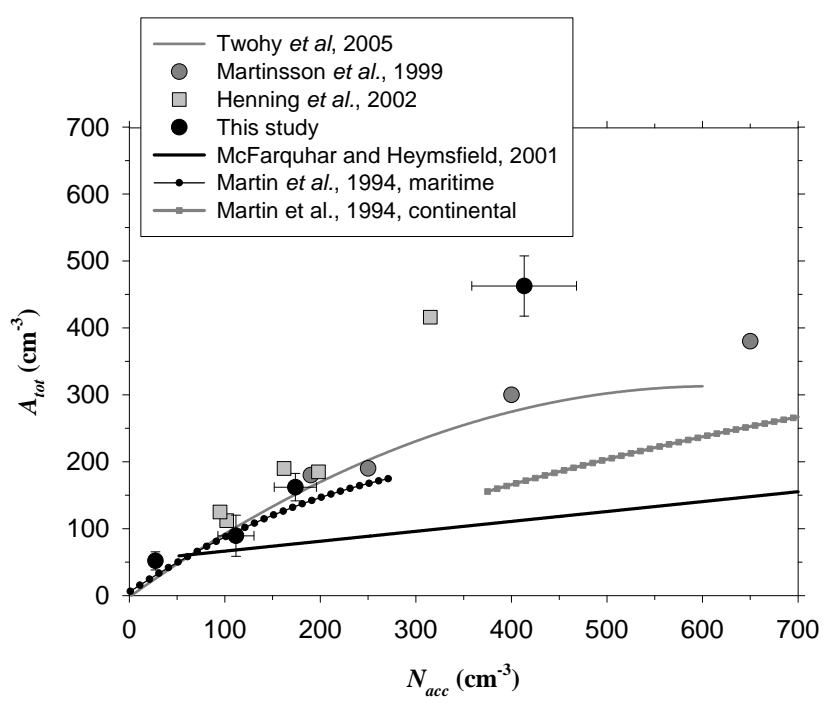

Fig. 5. Formed cloud droplets as a function aerosol concentration accumulation mode in different events, error bars are represents standard deviation during the event. As a comparison are also measurement by Twohy et al. (2005), Martinsson et al. (1999), Henning et al. (2002), MacFarquhar and Heymsfield (2001), and Martin et al. (1994).

further divided into three classed according to the measured LWC. As one might expect, $R_{\text {eff }}$ was larger for higher values of LWC and decreased clearly with the increasing total aerosol number concentration for each LWC category. The observed value range of $R_{\text {eff }}$ was relatively large, ranging from 3.7 to $14.9 \mu \mathrm{m}$. Overall, our findings are in qualitative agreement with those made in other ground-based or aircraft studies (Henning et al., 2002; Twohy et al., 2005; Freud et al., 2008).

We calculated also the aerosol indirect effect (IE), or aerosol-cloud interaction (ACI), by using Eq. (3) and obtained the value of 0.24 ( $R^{2}$ of the fitting was 0.61$)$. This can be compared to values reported for several different studies and platforms by McComiskey and Feingold (2008), in which ACI covers nearly the range between 0.02 and 0.33 . Many of the reported values of ACI are significantly less than the value of 0.27 proposed by Twomey (1974). The value obtained by us is very close to that by Twomey (1974) as well as the values reported by Gultepe et al. (1996) for aircraft measurements near Yarmouth in Nova Scotia (0.23), Martin et al. (1994) (0.25; for sites see above) and Twohy et al. (2005) ( 0.27 ; for sites see above). All these studies represent in situ airborne measurements.

\subsection{Chemistry of the aerosol phase}

The inorganic ion concentrations of the collected aerosol samples are presented in Table 3 for two size fractions. The total particle mass concentrations ranged from 1.0 to

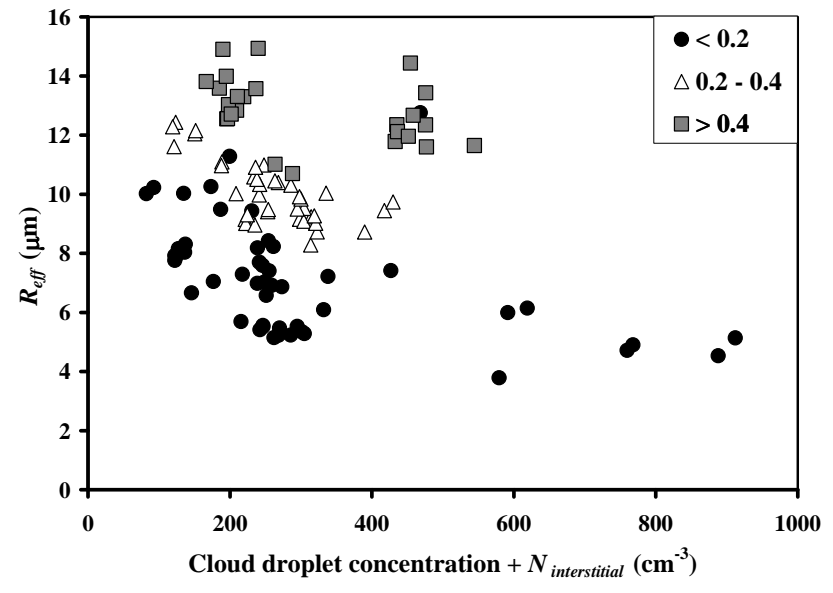

Fig. 6. Effective cloud droplet radius, $R_{\text {eff }}$, as a function of total aerosol number concentration divided according LWC (in the box in $\mathrm{g} \mathrm{m}^{-3}$ ).

$6.1 \mu \mathrm{g} \mathrm{m}^{-3}$ with collection times from two to four days. The VI results were compared to the SDI results, and the measured concentrations were in good agreement. The maximum differences were 11 and $7 \%$ for the $\mathrm{SO}_{4}^{2-}$ and $\mathrm{NH}_{4}^{+}$concentration, respectively. The chemical mass closure (the ratio between the chemically-derived and gravimetric mass of particles) for the fine size fraction varied between 0.92 and 1.32 when using a factor of 1.6 for converting the OC concentration into particulate organic matter (POM). This factor was slightly higher than that used by Saarikoski et al. (2005) for a background area. In the coarse size fraction, the mass closure was not as good because of larger amounts of insoluble crustal matter that was not analysed. Methane sulfonic acid and oxalate are not reported here, since their concentrations were close to the detection limits.

The rather long collection times prevented us from dividing the results into different source areas, yet some general features can be found. During the first and third sampling periods (19-21 and 23-27 October, respectively), continental air masses prevailed according to the air mass trajectories. This can also be seen from the chemical aerosol composition. Gravimetric mass concentrations were high during these periods, $\mathrm{SO}_{4}^{2-}$ was the dominant ionic species, and $\mathrm{Cl}^{-}$ and $\mathrm{Na}^{+}$concentrations were low. During the second and four sampling periods when marine air masses from Arctic Ocean were prevailing, gravimetric mass and $\mathrm{SO}_{4}^{2-}$ concentrations were low and both $\mathrm{Cl}^{-}$and $\mathrm{Na}^{+}$were abundant in the coarse size fraction. In general, POM was clearly the dominant component in marine background cases, whereas in continental cases $\mathrm{SO}_{4}^{2-}$ dominated the aerosol composition. 


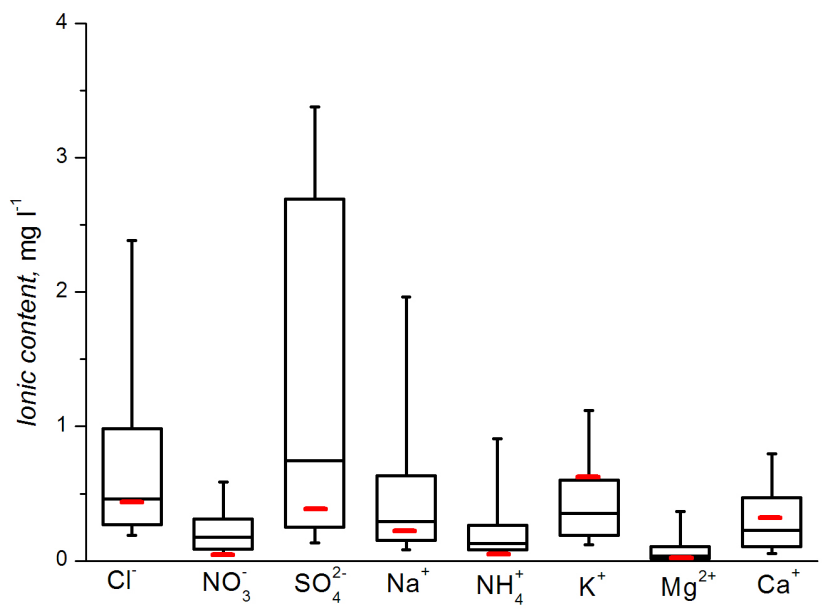

Fig. 7. The major inorganic ions in the collected cloud water samples. For each component, the median is shown, as well as 25 th and 75th, and 10th and 90th percentiles as boxes and vertical bars, respectively. The red horizontal line denotes detection limit, calculated as three times the standard deviation of field blanks.

\subsection{Chemistry of the liquid phase}

An overview of the concentrations of the major inorganic ions in cloud water is presented in Fig. 7. The detection limits were mostly governed by the field sampling procedure, and were determined as three times the standard deviation of field blanks, which were taken during each cloud event. The detection limits are $390 \mu \mathrm{g} / \mathrm{l}$ for $\mathrm{SO}_{4}^{2-}, 440 \mu \mathrm{g} / \mathrm{l}$ for $\mathrm{Cl}^{-}, 220 \mu \mathrm{g} / \mathrm{l}$ for $\mathrm{Na}^{+}, 620 \mu \mathrm{g} / \mathrm{l}$ for $\mathrm{K}^{+}, 320 \mu \mathrm{g} / \mathrm{l}$ for $\mathrm{Ca}^{2+}, 50 \mu \mathrm{g} / \mathrm{l}$ for $\mathrm{NH}_{4}^{+}$and $20 \mu \mathrm{g} / \mathrm{l}$ for $\mathrm{Mg}^{2+}$. The total ionic content (TIC) ranged from 0.61 to $37.37 \mathrm{mg} / \mathrm{l}$ with a median of $3.41 \mathrm{mg} / \mathrm{l}$ and standard deviation of $7.33 \mathrm{mg} / \mathrm{l}$. The median concentration corresponds to $99.7 \mu \mathrm{eq} / \mathrm{l}$, which is close to the liquid water content weighted average of $98 \mu \mathrm{eq} / \mathrm{l}$ measured at Jungfrauhoch, Switzerland (Baltensperger et al., 1998) but lower than the median TIC of $11 \mathrm{mg} / \mathrm{l}$ found in Puy de Dôme (Marinoni et al., 2004). Substantially larger values of TIC have been reported for sites closer to urban areas (see Baltensperger et al., 1998, and Marinoni et al., 2004, for references).

The changes in the total ionic content and relative contributions from different ions were minor throughout the cloud events. In general, sulphate $\left(\mathrm{SO}_{4}^{2-}\right)$ was the most abundant ion with a median concentration of $767 \mu \mathrm{g} / \mathrm{l}$, followed by chloride $\left(\mathrm{Cl}^{-}\right)$and sodium $\left(\mathrm{Na}^{+}\right)$with median concentrations of 479 and $308 \mu \mathrm{g} / \mathrm{l}$, respectively. Although the concentrations of potassium $\left(\mathrm{K}^{+}\right)$and Calcium $\left(\mathrm{Ca}^{2+}\right)$ were quite high (356 and $236 \mu \mathrm{g} / \mathrm{l}$, respectively), they fell below the detection limit, being indicative of a positive artefact during sampling. As a result, the measured concentrations of these species should be taken with caution. Ammonium $\left(\mathrm{NH}_{4}^{+}\right)$ and magnesium $\left(\mathrm{Mg}^{2+}\right)$ had median concentrations of 135 and $37 \mu \mathrm{g} / \mathrm{l}$, respectively.

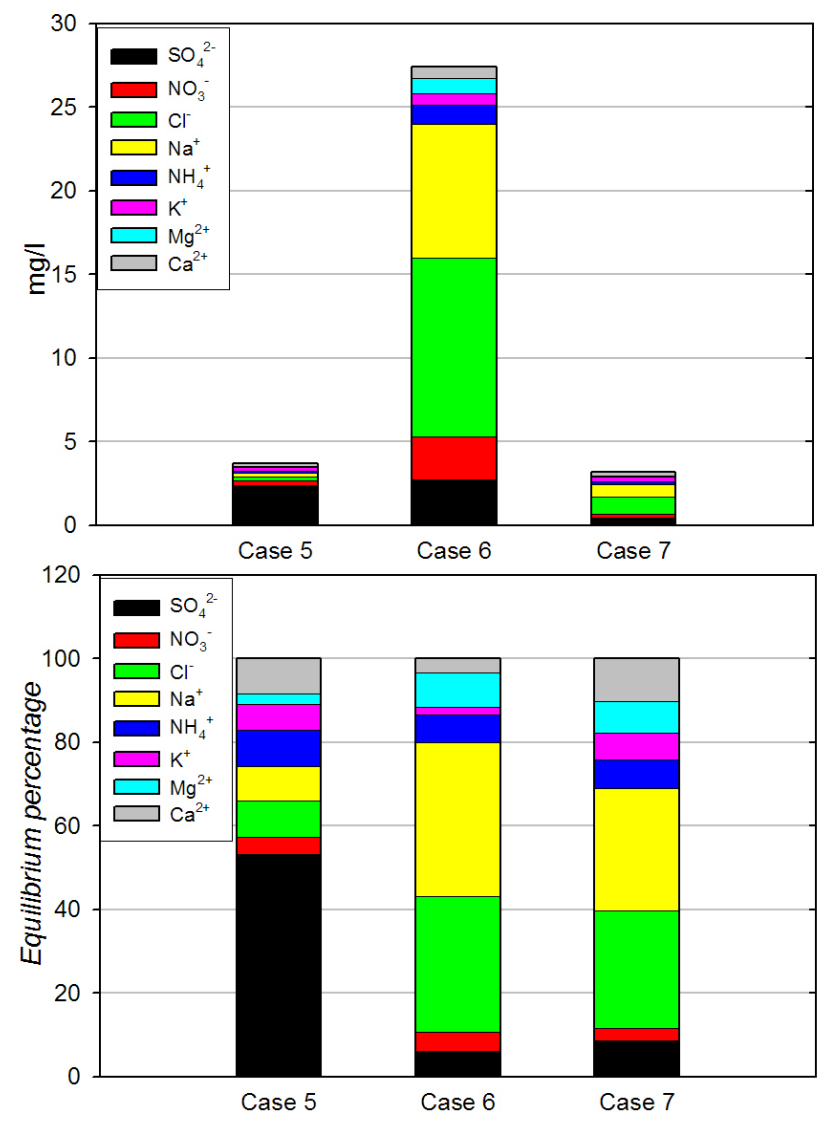

Fig. 8. Chemical composition of the cloud water during three different cases. Upper figure, absolute ion concentrations; lower figure, equilibrium percentage of main inorganic ions.

Due to the operational problems with the FSSP (see Sect. 2.2.1), only 17 data points were left for comparison with the cloud water chemical composition and FSSP data. Thus we present only shortly how TIC correlated with different parameters. It has been proposed, and also experimentally supported, that TIC should be inversely proportional to LWC (Junge, 1963; Möller et al., 1996; Elbert et al., 2000). We found a weak correlation $\left(R^{2}=0.38\right)$ between these two quantities. In fact, TIC correlated best with $R_{\text {eff }}\left(R^{2}=0.5\right)$. No correlation between the total aerosol load and TIC was observed. The cloud droplet number concentration varied only little between these 17 cases and no correlation between that quantity and TIC was found.

Three cases with different air mass origin are presented in Fig. 8 and summarized below:

CASE 5: continental air mass (26 October, day of the year: $300.38-300.99)$. A low total ionic concentration of $3.7 \mathrm{mg} / \mathrm{l}$ was measured. $\mathrm{SO}_{4}^{2-}$ dominated the equivalent distribution, with contribution of 53.1 eq. \%. Other ions were distributed quite evenly. The liquid water content, effective radius, total aerosol number concentration and cloud droplet number concentration were equal to $0.25 \mathrm{~g} \mathrm{~cm}^{-3}, 9 \mu \mathrm{m}, 260 \mathrm{~cm}^{-3}$ and 
Table 3. The concentrations of mass, OC, EC and inorganic ions for the two aerosol size fractions in $\mathrm{ng} / \mathrm{m}^{3}$. Samples were taken at the below cloud station.

\begin{tabular}{|c|c|c|c|c|c|c|c|c|c|c|c|}
\hline \multicolumn{12}{|c|}{ Fine $(<1.3 \mu \mathrm{m})$} \\
\hline Sample & Mass & $\mathrm{OC}$ & $\mathrm{EC}$ & $\mathrm{Cl}^{-}$ & $\mathrm{NO}_{3}^{-}$ & $\mathrm{SO}_{4}^{2-}$ & $\mathrm{Na}^{+}$ & $\mathrm{NH}_{4}^{+}$ & $\mathrm{K}^{+}$ & $M g^{2+}$ & $\mathrm{Ca}^{2+}$ \\
\hline $293-295$ & 2401 & 627 & b.d. & 95 & 19 & 1202 & 94 & 197 & 11 & 1 & 41 \\
\hline $295-297$ & 790 & 466 & b.d. & b.d. & 2 & 248 & b.d. & 29 & 1 & b.d. & b.d. \\
\hline $297-301$ & 1809 & 329 & b.d. & b.d. & 4 & 1018 & 5 & 79 & 1 & b.d. & b.d. \\
\hline $301-304$ & 560 & 206 & b.d. & 42 & 17 & 164 & 34 & 43 & 4 & 3 & 8 \\
\hline \multicolumn{12}{|c|}{ Coarse $(1.3-10 \mu \mathrm{m})$} \\
\hline Sample & Mass & $\mathrm{OC}$ & $\mathrm{EC}$ & $\mathrm{Cl}^{-}$ & $\mathrm{NO}_{3}^{-}$ & $\mathrm{SO}_{4}^{2-}$ & $\mathrm{Na}^{+}$ & $\mathrm{NH}_{4}^{+}$ & $\mathrm{K}^{+}$ & $M g^{2+}$ & $\mathrm{Ca}^{2+}$ \\
\hline $293-295$ & 3675 & 767 & 89 & b.d. & 44 & 72 & 26 & 23 & 4 & 3 & b.d. \\
\hline $295-297$ & 351 & b.d. & b.d. & 118 & 3 & 13 & 72 & 3 & 6 & b.d. & 75 \\
\hline $297-301$ & 463 & 579 & 64 & 1 & 7 & 73 & 4 & 6 & b.d. & 1 & b.d. \\
\hline $301-304$ & 447 & 266 & b.d. & 110 & 20 & 23 & 68 & 2 & 1 & 10 & b.d. \\
\hline
\end{tabular}

b.d. below detection limit

$85 \mathrm{~cm}^{-3}$, respectively. The total aerosol number concentration was calculated by adding together the number concentration of cloud droplets and cloud interstitial particles at the in-cloud station.

CASE 6: Mixed/arctic air mass (30 October, day of the year: 304.50-304.71). Arctic/mixed air masses went over northern Sweden prior to entering the measurement site. The total ion concentration in the cloud water was very high (27.2 $\mathrm{mg} / \mathrm{l}$ ), and $\mathrm{Na}^{+}$and $\mathrm{Cl}^{-}$dominated the cloud water composition with contributions of 36.8 and 32.5 eq. $\%$, respectively. The liquid water content, effective radius, total aerosol number concentration and cloud droplet number concentration were equal to $0.10 \mathrm{~g} \mathrm{~cm}^{-3}, 5 \mu \mathrm{m}, 730 \mathrm{~cm}^{-3}$ and $200 \mathrm{~cm}^{-3}$, respectively. These physical cloud parameters explained the high total ionic content.

CASE 7: arctic air mass (7 November, day of the year: 312.47-312.74) This case was characterized by a low total ionic concentration of $3.2 \mathrm{mg} / \mathrm{l}$. Na ${ }^{+}$and $\mathrm{Cl}^{-}$dominated the equivalent distribution, with $29.3 \%$ and $28.1 \%$ contributions. The $\mathrm{Na}^{+}$to $\mathrm{Cl}^{-}$concentration ratio of 1.05 was not very far from that in sea water $(0.86)$, which indicates that the sea-salt particles activated into cloud droplets had not been significantly affected by various acid displacement reactions prior to entering the measurement site (see, e.g. Song and Carmichael, 1999). $\mathrm{Mg}^{2+}$ had a higher than average contribution with 7.6 eq. $\%$. Lower than average equivalent contributions were measured for $\mathrm{NH}_{4}^{+}(6.9 \%), \mathrm{SO}_{4}^{2-}(8.6 \%)$ and $\mathrm{K}^{+}(6.3 \%)$. The liquid water concentration, effective radius, total aerosol number concentration and cloud droplet number concentration were equal to $0.12 \mathrm{~g} \mathrm{~cm}^{-3}, 8 \mu \mathrm{m}, 230 \mathrm{~cm}^{-3}$ and $55 \mathrm{~cm}^{-3}$, respectively.

\subsection{Comparison of the aerosol and cloud water chemistry}

Comparing aerosol and cloud water compositions was not straightforward, since the collection periods of the aerosol samples were longer than those of the cloud water samples, and since the aerosol collection was also made during clear-sky conditions. In addition, gas phase species may have been contributed to the chemistry of the cloud water, in which case the solubility of different species plays a role. In Fig. 9 a comparison between aerosol and cloud water samples for $\mathrm{SO}_{4}^{2-}, \mathrm{NH}_{4}^{+}$and $\mathrm{Na}^{+}$are presented. The values of equivalent- $\%$ were calculated by using the total mass of components that were analysed from cloud water. The general features of these two time series agreed reasonably well with each other. A clear exception for this pattern was the period covering the days of the year 298-301, during which the cloud water concentrations of $\mathrm{SO}_{4}^{2-}$ and $\mathrm{NH}_{4}^{+}$went down and the corresponding aerosol concentrations showed clearly higher values. During the same period $\mathrm{Na}^{+}$(and $\mathrm{Cl}^{-}$) behaved in an opposite way. In both VI and SDI data, very low concentrations of all species in the coarse size fraction were observed during this period. According to air mass trajectories, there were two prevailing air mass origins during this period: during the first part of the period (days of the year: 298-299) Arctic air masses were dominant, whereas during the latter part of the period continental air masses prevailed. On the latter part only few cloud water samples were obtained. The total aerosol concentrations were clearly higher during the latter part of the period compared with the first part of it, reaching more than two time higher values for the accumulation mode. This probably caused the observed difference. On day 300 there 

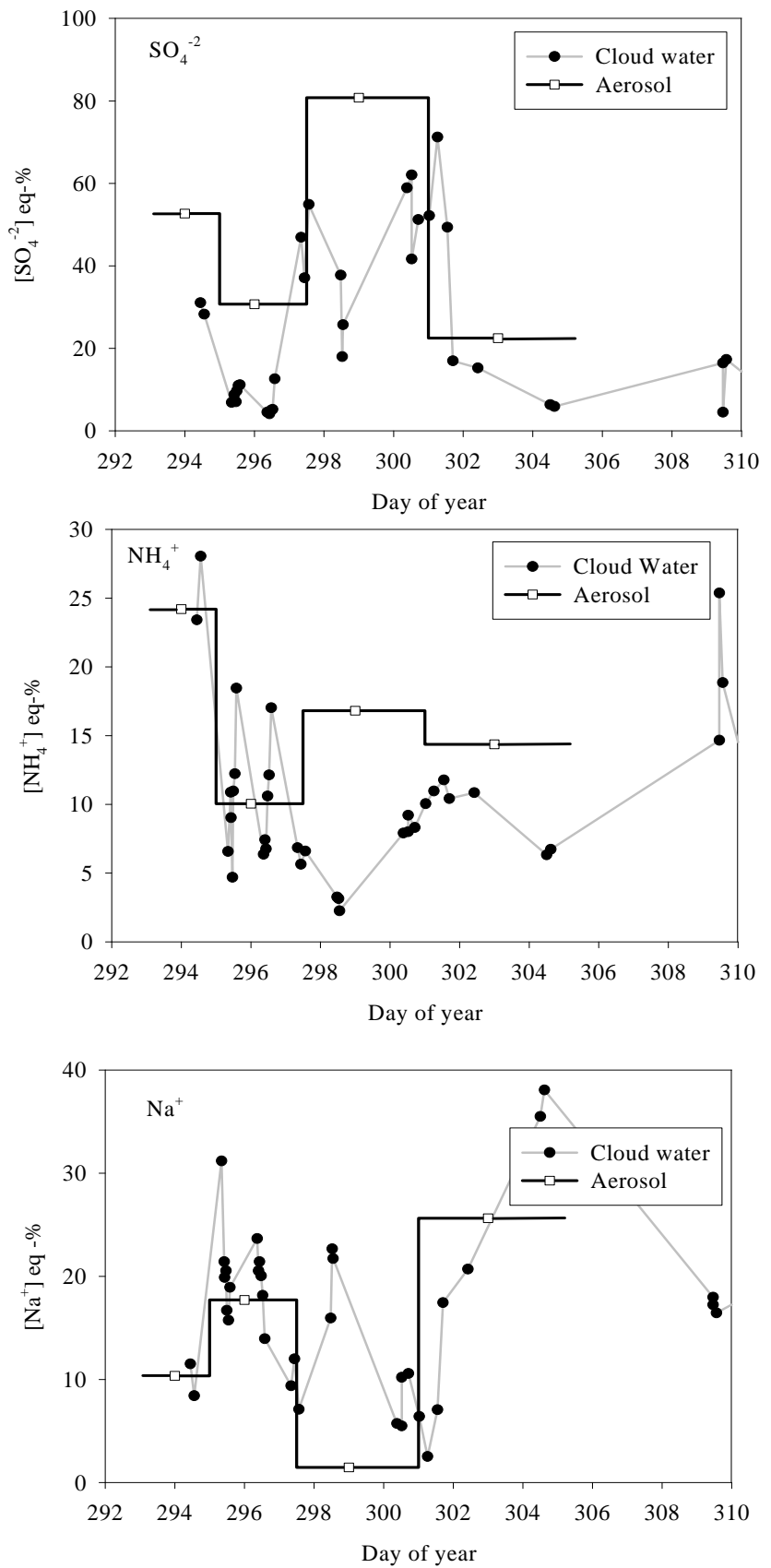

Fig. 9. Equivalent- $\%$ concentrations of various species in aerosol phase and cloud water during the campaign. On top is sulphate, in the middle ammonium and at the bottom sodium.

was some rain throughout the day $\left(0.1-0.6 \mathrm{~mm} \mathrm{~h}^{-1}\right)$, which might have scavenged larger particles at the below-cloud station. During the days 298-301 of year, no cloud-free periods were observed.
The total ionic contents of aerosol and cloud water samples are presented in Table 4. In the aerosol phase, the values of equivalent- $\%$ were calculated by using the total mass of components in Table 4. The cloud water concentrations were averaged over the aerosol sampling time. Generally, the aerosol samples contained clearly more $\mathrm{SO}_{4}^{2-}$ than the corresponding cloud water samples, except for the last sample period. The largest differences could be seen for the third sampling period (days of the year: 298-301), noticed already in Fig. 9. $\mathrm{K}^{+}$showed much higher concentrations in cloud than aerosol samples, which might be due to contamination of the cloud water. The cloud water samples contained generally more $\mathrm{Ca}^{2+}$ and $\mathrm{Mg}^{2+}$ than the corresponding aerosol samples. A similar observation was made by Decesari et al. (2005) in measurements made at Jeju Island. They suspected that $\mathrm{Ca}^{2+}$ was from the marine boundarylayer aerosol but would have been delivered within the liquid phase. It is interesting to notice that for the last sampling period the aerosol and cloud water concentrations were close to each other, even for $\mathrm{SO}_{4}^{2-}$, although half of the sampling period was free of clouds.

\section{Summary and conclusions}

This paper presents an overview of the results from the First Pallas Cloud Experiment (First PaCE), a three-week measurement campaign in fall 2004. The purpose of the First $\mathrm{PaCE}$ was to characterize the microphysical and chemical properties of aerosols and clouds and to find out how aerosol and cloud properties were connected to each other at background site in northern Finland. In situ ground-based measurements were made by taking the advance of having two measurements sites located $6 \mathrm{~km}$ apart at different altitudes. We found that our measurement approach is valid but that the results must be carefully screened in order to make sure that the same air masses are being measured at the two stations.

Our measurements demonstrate that different air mass types (e.g. marine vs. continental) have great influences not only on aerosol physico-chemical properties at a given measurement site, but also on cloud microphysics and chemistry over the same site. Clear indications of the Twomey effect were found: cloud droplet number concentration increased and cloud droplet effective radius decreased with an increasing aerosol amount. On the other hand, cloud droplet numbers concentrations were affected also by other quantities, such as the air updraft velocity controlled largely by the horizontal wind speed. When accumulation mode particle number concentrations were low, Aitken mode particles gave a significant contribution to the cloud droplet number population. 
Table 4. Ionic composition of the aerosol and cloud samples in equivalent-\%. Aerosol samples were taken at the below cloud station and cloud water samples in cloud station.

\begin{tabular}{lrrrrrrrrr}
\hline Aerosol sample Doy & \multicolumn{1}{c}{$\mathrm{Cl}^{-}$} & $\mathrm{NO}_{3}^{-}$ & $\mathrm{SO}_{4}^{2-}$ & $\mathrm{Na}^{+}$ & $\mathrm{NH}_{4}^{+}$ & $\mathrm{K}^{+}$ & $\mathrm{Mg}^{2+}$ & $\mathrm{Ca}^{2+}$ \\
\hline 293-295 & 5.31 & 2.02 & 52.67 & 10.35 & 24.20 & 0.73 & 0.61 & 4.10 \\
$295-297$ & 18.82 & 0.46 & 30.69 & 17.71 & 10.05 & 1.03 & b.d. & 21.24 \\
$297-301$ & 0.14 & 0.61 & 80.75 & 1.47 & 16.81 & 0.08 & 0.15 & b.d. \\
301-304 & 24.93 & 3.45 & 22.47 & 25.63 & 14.37 & 0.73 & 6.17 & 2.25 & \\
Cloud samples Doy & $\mathrm{Cl}^{-}$ & $\mathrm{NO}_{3}^{-}$ & $\mathrm{SO}_{4}^{2-}$ & $\mathrm{Na}^{+}$ & $\mathrm{NH}_{4}^{+}$ & $\mathrm{K}^{+}$ & $\mathrm{Mg}^{2+}$ & $\mathrm{Ca}^{2+}$ & No. of samples \\
\hline 293-295 & 11.68 & 2.22 & 22.07 & 17.03 & 19.35 & 10.27 & 3.88 & 13.49 & 3 \\
295-297 & 18.51 & 2.28 & 10.60 & 18.49 & 10.26 & b.d. & 6.99 & 19.34 & 13 \\
297-301 & 11.56 & 4.33 & 46.42 & 10.94 & 6.85 & b.d. & 2.23 & b.d. & 11 \\
$301-304$ & 20.02 & 3.26 & 21.98 & 20.17 & 9.84 & b.d. & 5.61 & b.d. & 4 \\
\hline
\end{tabular}

b.d. below detection limit

The chemical composition of the fine particle fraction was dominated by sulphate and POM in continental air masses, whereas in marine air POM was the dominant component in the fine particle fraction and sodium and chlorine in the coarse particle fraction. The inorganic chemistry of the cloud water was dominated by sulphate in continental air and by sodium and chlorine in marine air. The total inorganic ionic concentration of the cloud water correlated weakly with the inverse of the cloud liquid water content, but slightly better with the cloud droplet effective radius. The chemical compositions of aerosols and cloud water were in a quite good agreement, which indicates that gaseous compounds had not interfered significantly with the cloud water during the measurement period.

Although adiabatic cloud parcel simulations have demonstrated that cloud droplet number concentrations are affected by a number of factors (Kulmala et al., 1996; Nenes et al., 2001; Ervens et al., 2005; Romakkaniemi et al., 2005; Sorjamaa and Laaksonen, 2006), many large-scale models still rely on very simple relations between the aerosol amount and cloud droplet number concentration. A compilation of field experiments presented here shows that such simplistic approaches fail frequently, probably as a result of natural variations in air updraft velocity, shape of the particle number size distribution and aerosol chemical composition. Clearly, refined cloud droplet activation parameterizations, such as those by Abdul-Razzak and Ghan (2000) and Fountoukis and Nenes (2005), should be used whenever the atmospheric model carries some information on aerosol number size distribution and chemical composition.

Excluding remote marine areas (see, e.g. Hoppel et al., 1986), it has been traditionally though that Aitken mode particles can be neglected when considering the cloud droplet population. This study, together with some earlier observations (e.g. Henning et al., 2002; Komppula et al., 2005), point out that Aitken mode particles may contribute significantly to cloud droplet number concentrations in clean and moderately-polluted continental air, even at relatively low air updraft velocities typically encountered in stratiform clouds. This indicates that in the global atmosphere, cloud properties will be affected not only by primary particle emissions but also by atmospheric new-particle formation (see Spracklen et al., 2008).

Acknowledgements. This work was supported financially by the Tor and Maj Nessling Foundation and the Academy of Finland.

Edited by: D. Cziczo

\section{References}

Aalto, P., Hämeri, K., Becker, E., Weber, J., Salm, J., Mäkelä, J. M., Hoell, C., O’Dowd, C. D., Karlsson, H., Hansson, H.-C., Väkevä, M., Koponen, I. K., Buzorius, G., and Kulmala, M.: Physical characterization of aerosol particles during nucleation events, Tellus B, 53, 344-358, 2001.

Abdul-Razzak, H. and Ghan, S. J.: A parameterization of aerosol activation 2. Multiple aerosol types, J. Geophys. Res., 105, 6837-6844. 2000.

Anttila, T. and Kerminen, V.-M.: Influence of organic compounds on the cloud droplet activation: a model investigation concidering the volatility, water solubility, and surface activity of organic matter, J. Geophys. Res., 107(D22), 4662, doi:10.1029/2001JD001482, 2002.

Baker, M. B. and Peter, T.: Small-scale cloud processes and climate, Nature, 451, 299-300, 2008.

Baltensperger, U., Schwikowski, M., Jost, D. T., Nyeki, S., Gäggeler, H. W., and Poulida, O: Scavenging of atmospheric constituents in mixed phase clouds at the high-alpine site Jungfraujoch: Part I: Basic concept and cloud scavenging, Atmos. Environ., 32, 3975-3983, 1998..

Baron, P. A. and Willike, K.: Aerosol Measurement, second edition, John Wiley and Sons, New York, 143-195, 2001. 
Baumgardner, D., Strapp, W., and Dye, J.E.: Evaluation of the forward scattering spectrometer probe, Part II. Correction for coincidence and dead-time losses, J. Atmos. Ocean. Tech., 2, 626632, 1985.

Brenguier, J.: Coincidence and dead-time corrections for particle counters. part ii: High concentration measurements with an FSSP, J. Atmos. Ocean. Tech., 6, 585-598, 1989.

Bulgin, C. E., Palmer, P. I., Thomas, G. E., Arnold, C. P. G., Campmany, E., Carboni, E., Grainger, R. G., Poulsen, C., Siddans, R., and Lawrence, B. N.: Regional and seasonal variations of the Twomey indirect effect as observed by the ASTR-2 satellite instrument, Geophys. Res. Lett., 35, L02822, doi:10.1029/2007GL031394, 2008.

Decesari, S., Facchini, M. C., Fuzzi, S., McFiggans, G. B., Coe, H., and Bower, K. N.: The water-soluble organic component of sizesegregated aerosol,cloud water and wet depositions from Jeju Island during ACE-Asia, Atmos. Environ., 39, 211-222, 2005.

Ekman, A. M. L., Engtröm, A., and Wang, C.: The effect of aerosol composition and concentration on the development and anvil properties of a deep convective cloud, Q. J. Roy. Meteor. Soc., 133, 1439-1452, 2007.

Elbert, W., Hoffman, M. R., Krämer, M., Schmit, G., and Andreae, M. O.: Control of solute concentrations in cloud and fog water by liquid water content, Atmos. Environ., 34, 1109-1122, 2000.

Ervens, B., Feingold, G., and Kreidenweis, S. M.: Influence of water-soluble organic carbon on cloud drop number concentration, J. Geophys. Res., 110, D18211, doi: 10.1029/2004JD005634, 2005.

Feingold, G., Eberhard, W. L., Veron, D. E., and Previdi, M.: First measurements of the Twomey indirect effect using ground-based remote sensors, Geophys. Res. Lett., 30, 1287, doi:10.1029/2002GL016633, 2003.

Fountoukis, C. and Nenes, A.: Continued development of a cloud droplet formation parameterization for global climate models, J. Geophys. Res., 110, D11212, doi:10.1029/2004JD005591, 2005.

Freud, E., Rosenfeld, D., Andreae, M. O., Costa, A. A., and Artaxo, P.: Robust relations between $\mathrm{CCN}$ and the vertical evolution of cloud drop size distribution in deep convective clouds, Atmos. Chem. Phys., 8, 1661-1675, 2008,

http://www.atmos-chem-phys.net/8/1661/2008/.

Gultepe, I., Isaac, G. A., Leaitch, W. R., and Banic, C. M.: Parameterizations of marine stratus microphysics based on in-situ observations: Implications for GCMs, J. Clim., 9, 345-357, 1996.

Haglund, J. S. and McFarland, A. R.: A Circumferential Slot Virtual Impactor, Aerosol Sci. Technol., 38, 664-674, 2004.

Hatakka, J., Aalto, T., Aaltonen, V., Aurela, M., Hakola, H., Komppula, M,. Laurila, T., Lihavainen, H., Paatero, J., Salminen, K., and Viisanen, Y.: Boreal Environ. Res., 8, 365-384, 2003.

Henning, S., Weintgartner, E., Schmidt, S., Wendisch, M., Gäggeler, H. W., and Baltensberger, U.: Size-dependent aerosol activation at the high-alpine site Jungfraujoch (3580 ma.s.1.), Tellus B, 54, 82-95, 2002.

Hoppel, W. A., Frick, G. M., and Larson, R. E.: Effect of nonprecipitating clouds on the aerosol size distribution in the marine boundary layer, Geophys. Res. Lett., 13, 125-128, 1986.

IPCC: Summary for Policymakers. The Physical Science Basis. Contribution of Working Group I to the Fourth Assessment Report of the Intergovernmental Panel on Climate Change, in: Climate Change 2007, edited by: Solomon, S., Qin, D., Manning,
M., Chen, Z., Marquis, M., Averyt, K. B., Tignor, M., and Miller, H. L., Cambridge University Press, Cambridge, United Kingdom and New York, NY, USA, 4 pp., 2007.

Jokinen, V. and Mäkelä, J. M.: Closed-loop arrangement with critical orifice for DMA sheath/excess flow system, J. Aerosol Sci., 28, 643-648, 1997.

Junge, C. E.: Air chemistry and radioactivity, Academic Press, New York, 291-295, 1963.

Kivekäs, N., Kerminen, V. M., Anttila, T., Korhonen, H., Lihavainen, H., Komppula, M., and Kulmala, M.: Parameterization of cloud droplet activation using a simplified treatment of the aerosol number size distribution, J. Geophys. Res., 113, D15207, doi:10.1029/2007JD009676, 2008.

Komppula, M., Lihavainen, H., Kerminen, V.-M., Kulmala, M., and Viisanen, Y.: Measurements of cloud droplet activation of aerosol particles at a clean subarctic background site, J. Geophys. Res., 110, D06204, doi:10.1029/2004JD005200, 2005.

Koren, I., Remer, L. A., Kaufman, Y. J., Rudich, Y., and Martins, J. V.: On the twilight zone between clouds and aerosols, Geophys. Res. Lett., 34, L8805, doi:10.1029/2007GL029253, 2007.

Korhonen, H., Kerminen, V.-M., Lehtinen, K. E. J., and Kulmala, M.: CCN activation and cloud processing in sectional aerosol models with low size resolution, Atmos. Chem. Phys., 5, 25612570, 2005, http://www.atmos-chem-phys.net/5/2561/2005/.

Korhonen, P. and Viisanen, Y.: A Fogwater Collector for High Flow Velocities, J. Aerosol Sci., 26, Suppl 1, S805-S806, 1995.

Kulmala, M., Korhonen, P., Vesala, T., Hansson, H.-C., Noone, K., and Svenningsson, B.: The effect of hygroscopicity on cloud droplet formation, Tellus B,48, 347-360, 1996

Liu, Y., Daum, P. H., McGraw, R. L., Miller, M. A., and Niu, S.: Theoretical expression for the autoconversion rate of the cloud droplet number concentration, Geophys. Res. Lett., 34, L16821, doi:10.1029/2007GL030389, 2007.

Lohmann, U. and Feichter, J.: Global indirect aerosol effects: a review, Atmos. Chem. Phys., 5, 715-737, 2005, http://www.atmos-chem-phys.net/5/715/2005/.

Loo, B. W. and Cork, C. P.: Development of high efficiency virtual impactor, Aerosol Sci. Technol., 9, 167-176, 1988.

Lu, M.-L. and Seinfeld, J. H.: Effect of aerosol number concentration on cloud droplet dispersion: A large-eddy simulation study and implications for aerosol indirect forcing, J. Geophys. Res., 111, D02207, doi:10.1029/2005JD006419, 2006.

Maenhaut, W., Hillamo, R., Mäkelä, T., Jaffrezo, J.-L., Bergin, J.L., and Davidson, M. H.: A new cascade impactor for aerosol sampling with subsequent PIXE analysis, Nucl. Instrum. Meth. B, 109/110, 482-487, 1996.

Marinoni, A., Laj, P., Sellegri, K., and Mailhot, G.: Cloud chemistry at the Puy de Dme: variability and relationships with environmental factors, Atmos. Chem. Phys., 4, 715-728, 2004, http://www.atmos-chem-phys.net/4/715/2004/.

Martin, G. M., Johnson, D. W., and Spice, A.: The measurements and parameterization of effective radius of droplets in warm stratocumulus clouds, J. Atmos Sci., 51, 1823-1842, 1994.

Martinsson, B. G, Frank, G., Cedefelt, S., Swietlicki, E., Berg, O. H., Zhou, J., Bower, K. N., Bradbury, C., Birmili, W., Stratmann, F., Wendisch, M., Wiedensohler, A., and Yuskiewicz, B.A: Droplet nucleation and growth in orographic cloud in relation to the aerosol population, Atmos. Res., 50, 289-315, 1999. 
Mauger, G. S. and Norris, J. R.: Meteorological bias in satellite estimates of aerosol-cloud relationships, Geophys. Res. Lett., 34, L16824, doi:10.1029/2007GL029952, 2007.

McComiskey, A. and Feingold, G.: Quantifying error in the radiative forcing of the first indirect effect, Geophys. Res. Lett., 35, L02810, doi:10.1029/2007GL032667, 2008.

McFarland, A. R., Gong, H., Muyshondt, A., Wente, W. B., and Anand, N. K.: Aerosol Deposition in Bends with Turbulent Flow, Environ. Sci. Technol., 31, 3371-3377, 1997.

McFarquhar, G. M. and Heymsfield, A. J.: Parameterization of INDOEX microphysical measurements and calculations of cloud susceptibility: Applications for climate studies, J. Geophys. Res., 106, 28 675-28 698, 2001.

Myhre, G., Stordal, F., Johnsrud, M., Kaufman, Y. J., Rosenfeld, D., Storelvmo, T., Kristjansson, J. E., Berntsen, T. K., Myhre, A., and Isaksen, I. S. A.: Aerosol-cloud interaction inferred from MODIS satellite data and global aerosol models, Atmos. Chem. Phys., 7, 3081-3101, 2007, http://www.atmos-chem-phys.net/7/3081/2007/.

Möller, D., Acker, K., and Wieprecht, W.: A relationship between liquid water content and chemical composition on clouds, Atmos. Res., 41, 321-335, 1996.

Nenes, A., Ghan, S., Abdul-Razzak, H., Chuang, P., and Seinfeld, J. H.: Kinetic limitations on cloud droplet formation and impact on cloud albedo, Tellus B, 53, 133-149, 2001.

Penner, J. E., Quaas, J., Storelvmo, T., Takemura, T., Boucher, O., Guo, H., Kirkevåg, A., Kristjánsson, J. E., and Seland, Ø.: Model intercomparison of indirect aerosol effects, Atmos. Chem. Phys., 6, 3391-3405, 2006, http://www.atmos-chem-phys.net/6/3391/2006/.

Quaas, J., Boucher, O., Bellouin, N., and Kinne, S.: Satellite-based estimate of the direct and indirect aerosol climate forcing, J. Geophys. Res., 113, D05204, doi:10.1029/2007JD008962, 2008.

Romakkaniemi, S., Kokkola, H., and Laaksonen, A.: Soluble trace gas effect on cloud condensation nuclei activation: Influence of initial equilibration on cloud model results, J. Geophys. Res., 110, D15202, doi:10.1029/2004JD005364, 2005.
Rosenfeld, D. and Lensky, I. M.: Satellite-based insights into precipitation formation processes in continental and maritime convective clouds, B. Am. Meteorol. Soc., 79, 2457-2476, 1998.

Saarikoski, S., Mäkelä, T., Hillamo, R., Aalto, P. P., Kerminen, V-M., and Kulmala, M.: Physico-chemical characterization and mass closure of size-segregated atmospheric aerosols in Hyytiälä, Finland, Boreal Environ. Res., 10, 385-400, 2005.

Seinfeld, J. H. and Pandis, S. N.: Atmospheric Chemistry and Physics, John Wiley and Sons, New Jersey, 790 pp., 2006

Song, C. H. and Carmichael, G. R.: The aging process of naturally emitted aerosol (sea-salt and mineral aerosol) during long range transport, Atmos. Environ., 33, 2203-2218, 1999.

Sorjamaa, R. and Laaksonen, A.: The influence of surfactant properties on critical supersaturations of cloud condensation nuclei, J. Aerosol Sci., 37, 1730-1736, 2006.

Spracklen, D. V., Carslaw, K. S., Kulmala, M., Kerminen, V.-M., Sihto, S.-L., Riipinen, I., Merikanto, J., Mann, G. W., Chipperfield, M. P., Wiedensohler, A., Birmili, W., and Lihavainen, H.: Contribution of particle formation to global cloud condensation nuclei concentrations, Geophys. Res. Lett., 35, L06808, doi:10.1029/2007GL033038, 2008.

Stohl, A. and Seibert, P.: Accuracy of trajectories as determined from the conservation of meteorological tracers, Q. J. Roy. Meteor. Soc., 125, 1465-1484, 1998.

Twohy, C. H., Petters, M. D., Snider, J. R., Stevens, B., Tahnk, W., Wetzel, M., Russel, L., and Burnet, F.: Evaluation of the aerosol indirect effect in marine stratocumulus clouds: Droplet number, size, liquid water path, and radiative impact, J. Geophys. Res., 110, D08203, doi:10.1029/2004JD005116, 2005.

Twomey, S.: Pollution and the planetary albedo, Atmos. Environ., 8, 1251-1256, 1974.

Winklmayr, W., Reischl, G. P., Linder, A. O., and Berner, A.: A new electromobility spectrometer for the measurement of aerosol size distribution in the size range 1 to $1000 \mathrm{~nm}$, J. Aerosol Sci., 22, 289-296, 1991. 